Article

\title{
Welfare Mediators as Game Changers? Deconstructing Power Asymmetries Between EU Migrants and Welfare Administrators
}

\author{
Nora Ratzmann ${ }^{1, *}$ and Anita Heindlmaier ${ }^{2,3}$ \\ ${ }^{1}$ Centre for Analysis of Social Exclusion, London School of Economics, UK \\ ${ }^{2}$ Salzburg Centre of European Union Studies, University of Salzburg, Austria \\ ${ }^{3}$ Department of Political Science and Sociology, University of Salzburg, Austria \\ * Corresponding author (n.ratzmann@lse.ac.uk)
}

Submitted: 29 June 2021 | Accepted: 16 September 2021 | Published: 22 March 2022

\begin{abstract}
Under EU law, EU citizens constitute a particular group of immigrants, as they can, mostly without restrictions, move to, and reside in, another EU country, enjoying equal treatment with nationals in terms of accessing employment and social rights. However, as this article demonstrates, the settlement of EU citizens in another member state does not happen without hurdles. Through a careful in-depth study of access to transnational welfare rights in practice, we analyse knowledge and resulting power asymmetries impacting interactions between certain EU migrant claimants and street-level bureaucrats in Austrian and German social administrations. Following an inductive approach, based on an extensive data set of 144 qualitative interviews, this article first unpacks the different types of knowledge asymmetries relating to administrative procedures, formal social entitlements and the German language. We then analyse how such knowledge asymmetries may open space for welfare mediation in order to compensate for a lack of German language skills and to clarify misunderstandings about legal entitlements and obligations embedded in the claims system. Finally, our contribution offers a typology of welfare mediators and their characteristics, as not all types can be regarded as equally effective in reshaping power asymmetries. Overall, this article allows for insights into how welfare mediators, as more or less institutionalised opportunity structures, can shift policy outcomes in unexpected ways, enabling access to social benefits and services for otherwise excluded EU migrant citizens working, or seeking to work, in another EU member state.
\end{abstract}

\section{Keywords}

European Union; free movement; migration; non-take-up; social assistance benefits; street-level bureaucracy; welfare mediators

\section{Issue}

This article is part of the issue "Transnational Social Protection: Inclusion for Whom? Theoretical Reflections and Migrant Experiences" edited by Elisabeth Scheibelhofer (University of Vienna), Emma Carmel (University of Bath), and Anna Amelina (University of Cottbus).

(C) 2022 by the author(s); licensee Cogitatio (Lisbon, Portugal). This article is licensed under a Creative Commons Attribution 4.0 International License (CC BY).

\section{Introduction}

EU migrant citizens living in a different member state to that whose citizenship they hold enjoy freedom of movement within the EU and transnational social rights, such as entitlements, to certain social subsistence benefits, if they need financial support and fulfil certain, yet vague, eligibility criteria. As research has already demonstrated, many face difficulties in asserting such rights in practice. Ambiguous legal entitlements to social benefits do not always translate into receipt of those benefits (see Amelina et al., 2020; Kramer et al., 2018).

While EU law already foresees barriers to social entitlements, additional hurdles arise. Broadly speaking, barriers to social assistance benefit receipt can relate to claimants' individual circumstances (Tuckett, 2015), and system-immanent barriers (see Dittmar, 2016). For instance, local welfare administrators may interpret 
loosely defined eligibility conditions, such as lawful residence (Heindlmaier \& Blauberger, 2017) or habitual residence (Bruzelius, 2019), in a restrictive way and erect indirect barriers to claiming social benefits. In addition to the interpretation of vague technical criteria, stereotyped perceptions of certain EU claimant groups, and related individual judgements that a claimant is undeserving to claim can impede de facto access to social benefits (Ratzmann, 2021).

This contribution seeks to address how the interplay between individual resources and institutional hurdles shapes benefit access in practice, via the interaction processes between EU migrant claimants on the one hand, and street-level bureaucrats on the other, i.e., local welfare administrators as representatives of the state apparatus at street-level. This includes interactions between street-level bureaucrats and claimants, both face-to-face and via papers or email, but also how other third-party actors intervene as mediators at street-level, if necessary. As we know from the street-level bureaucracy literature (pioneered by Lipsky, 1980), it is during this administrative encounter that claims to social assistance are negotiated and put into effect. Streetlevel bureaucrats may use their discretion in administering benefits in order to apply the law in a more strict or lenient way (e.g., Dubois, 2010; Marrow, 2009). For instance, even if there is little discretion in how local administrators can apply eligibility criteria, procedural discretion can be exercised in decisions-about the documentation required for processing a claim, the nature of support offered during the application process, the number of face-to-face meetings demanded, the timing of appointments, or the waiting times for processing a claim. In short, informal discretion creates the potential for different treatment when processing benefit claims, which goes beyond erroneous interpretation of the legal and administrative framework.

Scholarship on street-level bureaucracy to date has mostly examined the "unequal relationship" between street-level bureaucrats and claimants in national contexts (e.g., Dubois, 2010, p. 47; Lipsky, 1980, p. 60; Scheibelhofer et al., 2021), commonly relating to class and skill level. To uncover potential barriers to substantive access to transnational welfare rights in Austrian and German welfare administrations, this article analyses potential knowledge asymmetries that could impact interactions between EU migrant claimants of working age in need of financial support, and street-level bureaucrats during the claiming procedure, focussing on social assistance. Following an inductive approachand based on an extensive data set of 144 qualitative interviews in Germany and Austria with street-level bureaucrats, key informants such as representatives from rights advocacy groups and welfare organisations, and EU migrants themselves-our contribution unpacks the different types of knowledge asymmetries relating to formal social entitlements, administrative procedures, and the German language that impact access in practice.
We consider the group of EU migrant claimants worthwhile examining because they are a particular group, given that they should enjoy equal treatment as nationals when living in another EU member state, while their social assistance entitlements commonly remain loosely defined and imprecise under EU law (see the Supplementary File). In the EU multilevel governance context, a complex set of provisions at both the EU and the national level needs to be consulted, including case-specific judgments of the European Court of Justice (Blauberger \& Schmidt, 2017). When it comes to EU citizens who are in atypical employment, implying few hours and/or little remuneration, or those who remain non-active when settling in an EU member state whose citizenship they do not hold, social entitlements remain particularly ambiguous and EU member states need to engage in individual assessments (Carmel \& Paul, 2013; Martinsen et al., 2019).

For instance, while workers are entitled to receive equal treatment and, hence, benefit access under EU law, the rather fuzzy legal definition of a "worker" as any person who pursues "effective and genuine activities, to the exclusion of activities on such a small scale as to be regarded as completely marginal and ancillary" (D. M. Levin v Staatssecretaris van Justitie, 1982, para. 17) opens room for procedural discretion (Brodkin \& Majmundar, 2010) during local claims-processing for workers in atypical employment. Economically inactive migrants, for their part, could be eligible for benefits, inter alia if they reside lawfully in another EU member state, fulfilling the vague criterion of having "sufficient resources" not to become a burden on the social assistance system of their country of destination (Directive 2004/38/EC of the European Parliament and of the Council of 29 April 2004, 2004), and if they can demonstrate a "certain link" to the society of destinationat least prior to the European Court of Justice cases of Elisabeta Dano and Florin Dano v Jobcenter Leipzig (2014) and Jobcenter Berlin Neukölln v Nazifa Alimanovic and Others (2015) which restricted access to the five years residency threshold (see Martinsen et al., 2019). However, they can be expelled, and may fear being expelled, if constituting an "unreasonable burden" to the social assistance system when claiming social assistance benefits (Heindlmaier \& Blauberger, 2017). EU migrants may de facto find themselves in precarious situations in a "schizophrenic welfare state" (Lafleur \& Mescoli, 2018).

Thus, while EU migrant citizens have the right to move freely within the EU, albeit conditionally, and should not be discriminated against according to the consolidated version of the Treaty on the Functioning of the European Union (2012), the ambiguous character of EU law concerning EU migrants' transnational social rights adds an additional layer of complexity, typically to the detriment of EU migrants. The findings, while focussing on the lived experience of EU migrants, may pertain to the needs of an increasingly diverse migrant client population, as some of the hurdles relate 
to their position as foreigners, or outsiders with regard to an often unfamiliar bureaucratic system (Ratzmann, 2019). This status can create compounding effects with characteristics such as educational or class background, which could affect the claiming process for nationals and non-nationals alike (Dubois, 2014). In short, we argue that knowledge asymmetries between claimants and street-level bureaucrats are reinforced in the context of EU freedom of movement, due to the existing legal provisions which create a weak legal position for EU migrants vis-à-vis local administrators from the outset-and ambiguities which increase the room for administrative discretion in claims-processing. Street-level bureaucrats may facilitate or restrict de facto benefit receipt depending on their discretionary decisions.

Our contribution further highlights how such knowledge asymmetries open space for mediation into the welfare system. We focus on how such knowledge asymmetries can be resolved or negotiated in practice through third parties who, as "activist" parties, mediate access to social assistance benefits for their clients. We demonstrate how such individual welfare mediators intervene in the street-level interaction and may overturn the unequal relationship between local welfare administrators and EU migrant claimants by cushioning some of the knowledge asymmetries described. We specifically chose to conceptualise these third parties intervening in the street-level interaction as welfare mediators, rather than intermediaries - as our data showed such individuals primarily as advising and supporting claimants, rather than occupying a go-between, intermediate position brokering in both directions. Their main role is to smooth the path to accessing social benefits in practice, acting on behalf of their clients as "welfare influencers," taking on an activist role on the individual level. Such welfare mediators may inform EU migrants about their social entitlements, accompany them to the relevant authority or inform them where to turn to, also exert pressure on the authority by legally challenging the decision to deny a claim (see Bruzelius, 2020), and act as language interpreters.

While migration research (de Jong, 2015; Infantino, 2013) has analysed how mediators can help to create weak bridging ties between individuals in order to facilitate the flow of information between new arrivals and the host society, their role has been studied less with respect to welfare administrations (except for Bruzelius, 2020, on the role of not-for-profit organisations as welfare intermediaries). The article highlights the often under-recognised role of welfare mediators and characterises them through a typology developed from our data, comprising designated migration counsellors such as welfare organisations, private mediators such as employment recruitment agencies, and personal relationships such as friends or partners. Our findings illustrate how de facto access to social benefits can be a highly mediated process, whereby third parties may strengthen EU migrant claimants' positions vis-à-vis street-level bureaucrats. Such a mediation process can take the form of supporting them in navigating social protection in the member state of residence more broadly, or by being present during the claiming interaction as translators.

The article is structured as follows: Section 2 gives an overview of the research design and data. Section 3 follows with a discussion on different types of knowledge asymmetries between EU migrants and welfare administrators. Section 4 explores how such asymmetries may be overturned through the intervention of welfare mediators and developing a typology of such mediators. Section 5, the discussion, highlights inter alia how knowledge asymmetries can translate into power asymmetries. Section 6 , our final section, concludes and points to possible avenues for future research.

\section{Research Design and Data}

Our inductive study draws upon empirical evidence from Germany and Austria, focussing on EU migrants of working age, and social benefits with a link to the labour market. The two EU member states studied have a high share of EU migrants who have lived in the countries for less than ten years, compared to long-term EU migrants (European Commission, 2020, p. 20). This, it could be argued, turns them into paradigmatic examples of destination countries for EU migrants whose social rights are vague, given that EU migrants only enjoy full equal treatment, and hence clear social entitlements, after reaching the lawful residence threshold of five years. When comparing our data across the German and Austrian cases, we did not observe noticeable differences between the two countries, which may relate to them both belonging to the same corporatist welfare tradition. This tradition is characterised by a strong not-for-profit sector acting as a partner implementing social services for the government in a tripartite welfare state.

Our findings build on two complementary qualitative data sets of 144 in-depth interviews conducted between 2015 and 2017 (see Table 1 for details). The research questions for the two data sets were similar in nature (though not identical, which offers some drawbacks in terms of comparability), focussing on EU migrants' (non-)access to social benefits and the reasons for such, as well as related hurdles. The interview topic guides comprised questions relating to knowledge of social entitlements and interactions between street-level administrators and EU migrant claimants.

The majority of the interviews in data set 1 were carried out in Berlin, which is, as Germany's biggest agglomeration with 3.6 million inhabitants, an interesting case. Berlin represents Germany's main migration hub, hosting three times more foreign nationals (accounting for 19 percent of its population) than the German average. About 38 percent of the foreign resident population are EU migrants, mostly Bulgarian, Romanian, Italian, and Polish nationals. By complementing data set 1 with data 
Table 1. Breakdown of in-depth interviews.

\begin{tabular}{|c|c|c|c|c|}
\hline \multirow[b]{2}{*}{ Interviews } & \multirow{2}{*}{$\begin{array}{l}\text { Data set } 1 \\
\text { Germany }\end{array}$} & \multicolumn{2}{|c|}{ Data set 2} & \multirow[b]{2}{*}{ Total (per interview category } \\
\hline & & Germany & Austria & \\
\hline $\begin{array}{l}\text { Key informants (policy-makers, legal experts, } \\
\text { migrant advisors, welfare organisations) }\end{array}$ & 32 & 7 & 8 & 47 \\
\hline EU migrants & 16 & 0 & 0 & 16 \\
\hline Welfare administrators & 55 & 9 & 17 & 81 \\
\hline Total (per country) & 103 & 16 & 25 & 144 \\
\hline
\end{tabular}

Note: For details on the data sets see Ratzmann (2019, pp. 74-95, data set 1) and Heindlmaier (2018, pp. 87-91, data set 2).

set 2, and so with further interviews across Germany and Austria, both in urban and in rural areas, our corpus of interviews seeks to give a more rounded picture of what is happening in the two member states. However, we acknowledge the limitation of including only a small number of interviews with EU migrant claimants, who were difficult to access, especially when experiencing vulnerability. We sought to offset this weakness by relying on key informant interviewees who gave an aggregated overview of EU citizens' claiming experiences. Although beyond the scope of feasibility of our studies, further research could capture the voices of those concerned.

Key informant interviewees (such as diversity trainers, dedicated welfare, or EU migration counsellors from national welfare organisations or community-based associations, along with lawyers specialising in advising EU migrants) gave a comprehensive overview of EU citizens' claiming experiences from a third-party perspective. Conversations with welfare administrators provided insights into the day-to-day working routines of welfare authorities and the interaction with EU migrants from the perspective of street-level bureaucrats, at different levels of the hierarchy and within the main organizational units.

The complementary claimant interviews in Germany helped to uncover EU migrant citizens' subjective interpretations of their interactions with local bureaucracy. To reflect EU citizens' diversity of circumstances, the sample considered a range of gender, ages, and education levels. Regarding their citizenship status, selected interviewees were EU migrants who had moved from another EU country to Germany after the 2004 Eastern enlargement, but who had not reached the five-year permanent residency threshold, which would guarantee full equal treatment with nationals, at the time of the (potential) claim. About half of the selected respondents came from (South-)Eastern European countries, such as Bulgaria, Hungary, and Poland, while the majority of Southern and Western European respondents were French or Spanish nationals. Respondents were recruited following a snowball-sampling approached, based on three criteria: (a) to be of working age (15-67), (b) to have experienced a period of unemployment or underemployment since the 2005 "Hartz" reforms that pro- foundly changed the German social assistance system (defining their need of basic social support, but not necessarily their legal eligibility), and (c) to be an EU migrant who had not reached the five-year permanent residency threshold at the time of the (potential) claim. Following an iterative and inductive approach, transcripts and interview notes were coded after each round of fieldwork, using emergent themes and categories.

\section{Knowledge Asymmetries Between EU Migrant Claimants and Welfare Administrators}

Following Warin (2010), three reasons for non-take-up of social benefits can be distinguished: a lack of awareness of entitlements, withdrawal of the benefit application by the claimant, or a denial of benefit by street-level bureaucrats despite legal eligibility (see also van Oorschot, 1991, p. 20). To better grasp the interactive dynamics between street-level bureaucrats in Germany and Austria, and EU migrants living and claiming social assistance in those EU member states as foreign citizens, this section unravels the different types of asymmetries of knowledge between the two interacting parties, which may contribute to, or lead to, non-take-up.

We consider this to be a pertinent question, as we observed in our research how knowledge asymmetries may render EU migrant claimants more vulnerable and less able to affirm their legal entitlementsor, in other words, reinforce existing power asymmetries at street-level. For instance, we could see that those EU migrant claimants who are not fully aware of their legal entitlements and inquire at the welfare authority about their social rights, tend to have higher chances of being turned away and being denied their claim in practice compared to those who are able to assert their social rights (Ratzmann, 2020). The data illustrate that this experience was shared by several respondents of different nationalities and educational backgrounds we interviewed, who did not "know their rights in Germany" (from interviews with EU citizens in Germany). EU migrant applicants who approached the institution with a request for more information, and unable to make their case due to informational gaps, may have their application rejected in the entrance zone 
without a formal screening, violating the official directives set out by the Federal Agency for Employment, the German guiding institution for social assistance benefits and job mediation (interviews with key informants, Germany). For instance, a French couple in their mid-30s, both well educated, reported on their experience of being sent away by a receptionist at their local job centre office in Berlin. Here, their lack of knowledge of their legal entitlements could not be offset by their social status as young, qualified Western EU citizens. When they requested more information as "newcomers of how things work here" in Germany, the young couple, who had recently arrived in Berlin, was told that "as newly arrived, [they would] not get any support." They were not provided with any further explanation. Equally in Austria, key informants reported how some local welfare bureaucrats would send away those EU migrants who wanted to submit their application for benefits, arguing that they were not entitled to draw benefits, as well as EU migrants not questioning local administrators' judgements.

Overall, the relationship between welfare administrators and claimants can be characterised as "structurally asymmetrical" or "unequal" (Dubois, 2010). Street-level bureaucrats supply claimants with essential services, which cannot be obtained elsewhere, and thus hold an inherent power position in relation to the claimant (Demazière, 1996, p. 7), even if street-level bureaucrats themselves may follow instructions from superiors, which carry signalling effects, in their decisions (Martinsen et al., 2019). In the context of EU migration and transnational social rights, we identified three types of knowledge asymmetries, based on an inductive analysis of the collected data, and an iterative reading of existing scholarship. We consider unequal positioning within the street-level interaction to relate to EU migrant applicants' knowledge of (a) formal social entitlements, (b) administrative procedures, and (c) the German language, which contribute to the shaping of their interactions with local welfare bureaucracies.

While the bespoke dimensions could be considered hurdles originating in the institutional structures of social administrations, and hence also be faced by other claimants, born and raised in Germany, legal ambiguities regarding EU citizens' entitlements can exacerbate the trend, and hence allow for an interesting case in point. Depending on the gaps in their knowledge, which can emerge concurrently but do not have to, we argue that claimants are more or less able to meet the implicit demands embedded in the claimingprocess in order to gain de facto access to social benefits. We focus on the claimant side, as street-level bureaucrats, through their professional role, are commonly advantaged over the claimant in having acquired such knowledge as a pre-requisite to exercising their occupation, even though not all do (see Heindlmaier, 2018; Ratzmann, 2019). This includes technical knowledge (Fachwissen) and awareness of day-to-day bureaucratic procedures (Dienstwissen; Weber, 1922, p. 129), as well as adequate language skills and a formal qualification which are typically required for the job (Eckhard, 2021, p. 309).

\subsection{Asymmetrical Information on Formal Social Entitlements}

As alluded to in the introduction, legal social entitlements of EU migrants tend to be ambiguous and complex if the claimants are involved in marginal employment or are economically inactive. Claimants explained how legal sources are often difficult to read and understand. Despite some persistent knowledge gaps, streetlevel bureaucrats tend to be aware of the general conditions of entitlement (Dubois, 2010, p. 49) or have guidelines at their disposal. In contrast, this information is not always accessible to claimants, leading to misconceptions about their social entitlements (Ratzmann, 2020). Several EU migrants explained that they did not know their social entitlements-as confirmed by other interviewees in both countries (welfare administrators, key informants)-which prevented some from applying for benefits (see also Ehata \& Seeleib-Kaiser, 2017). Newly arrived EU migrants were described as being particularly unaware of their legal entitlements by key informants in Austria and Germany. For others, insufficient knowledge of social rights engendered misunderstandings about what to expect. According to a key informant in Austria, several thought they had access to social benefits "once they simply lived in the country." Key informant interviews highlighted how EU migrants may be attracted by a different set of expectations of social benefits available in their destination country than what they are legally eligible for.

\subsection{Asymmetrical Procedural Knowledge}

Secondly, bureaucratic systems are complex in their procedures and vocabulary. Hence, manoeuvring within them requires "bureaucratic competence" (Gordon, 1975 ) and knowledge about where to turn to in the first place. Or, in the words of Tuckett $(2015$, p. 1), "successful encounters with bureaucratic systems require users to be familiar with 'insider' rules," a familiarity which claimants, as system-outsiders, do not necessarily have (Dubois, 2010, pp. 48-50). Several EU migrants recounted how, in contrast to German-born nationals, they were socialised in a different kind of society, which impacts their understanding of a bureaucracy. Similarly, some welfare administrators, who had themselves migrated to Germany during their childhood or adolescence, explained during the interview how such informal socialisation processes are likely to influence the applicants' ability to appropriately decipher a given socio-cultural and bureaucratic context:

Somebody who grew up in Germany... grows up with the social system and knows what to bring along and 
where to go, is familiar with the whole bureaucracy, having been socialised into this bureaucracy.

Through acculturation effects, their position as newcomers to the German language and the relevant administrative culture might slowly improve, reducing the associated risk of mistranslating implicit behavioural norms and welfare entitlements. This process could be captured by the idea of progressive assimilation, a concept first proposed by Chiswick et al. (2018) to describe immigrants' integration into a foreign labour market. Commonly, EU migrants described how they were often unfamiliar with the tacit procedural codes when they arrived in Germany or Austria, which tended to differ from the domestic context they grew up in. EU migrants also felt overwhelmed by the amount and types of documents they had to bring and did not understand why they had to bring certain documents, such as the registration certificate documenting lawful residence (interviews key informants, Austria and Germany). Many did not know "what exactly to do" or "which [benefit] to apply for" (interviews with EU migrants, Germany).

\subsection{Asymmetrical Knowledge of the German Language}

Closely intertwined with procedural knowledge are tacit cultural expectations, such as the ability to converse in the German language, which shape claimants' aptitude for interacting with national bureaucracies. There is a "certain unequal treatment of course already due to the language" when it comes to interactions between EU migrants and local administrators, said an interview key informant in Austria. As the data collected for this research indicate, EU foreign language claimants often feel discriminated against based on their inability to speak German, as this English-speaking interviewee living in Germany highlighted:

Sometimes I can speak English and they can understand. But from my experience, going through this process, more often than not, they will stop you and say: No.... I just remember the language being a huge problem.

Generally, claimants tend to be expected to speak the prevailing official national language in order to pursue "economic, political and social opportunities" (Brubaker, 2014 , p. 23). To be able to interact with monolinguallyoriented welfare authorities (Scheibelhofer et al., 2021), language skills appear decisive (see also Lipsky, 1980; Rice, 2013). From the perspective of welfare administrators, language remains a hurdle insofar as, "even if" they are willing to speak English, "foreign claimants themselves may not be able to do so" (interview with welfare administrators, Germany). This view, however, could be contested considering the administrative guidelines in German employment administrations, which stipulate that EU migrants ought to be provided with an inter- preter at no cost if unable to communicate in German (Bundesagentur für Arbeit, 2011, p. 1). Considering EU claimants' entitlements regarding interpreting and translating services, outsourcing of such tasks to the claimants themselves could be considered a form of discrimination.

\subsection{The Role of Educational Background}

Overall, knowledge asymmetries may hinder EU migrant applicants in asserting their social entitlements. However, they should not be considered as a homogenous group. According to the view of two welfare counsellors interviewed in Germany, educational level impacts on EU migrants' abilities to familiarise themselves with the host country setting. This includes both the learning of the German language, and understanding a new, complex administrative system, which Scheibelhofer and Holzinger (2018) qualified as "welfare learning." Following a similar line of thought, one of the community workers interviewed in Germany described those with lower educational levels as less prepared to acquire new knowledge:

These are commonly people who are not at all prepared for the situation. They do not know the language or things like how health insurance works or the difficulties of finding housing. Many of them work under ludicrous working conditions. Their lack of knowledge is often taken advantage of... many who have low levels of education, who only went to school for a few years [in their home country].

Within our sample, the well-educated gave the impression of being better prepared, or of being able to afford, and be more versatile in finding, help-compared to their less educated peers. In sum, as shown throughout our analysis, knowledge asymmetries can create vulnerabilities within the EU migrant group and lead to struggles in de facto claiming of social entitlements, depending on their preparedness to claim in an EU member state other than their own. We further note how welfare mediators can play a key role in bridging such knowledge asymmetries (Hasenfeld et al., 1987, p. 406). These mediators may enable de facto access to social benefits for those who have difficulties realising their claim in practice, which we turn to in the following.

\section{Overcoming Asymmetries through Welfare Mediators}

While welfare administrations can be seen as a locus of power in street-level interaction, crucial in deciding whether applicants can claim state support in relation to their welfare needs, third party actors often intervene in the process to overcome the described asymmetries. In other words, the ways in which different types of knowledge asymmetries play out in street-level interactions open space for welfare mediators to intervene 
on behalf of EU migrant claimants (for some of the pathways see Ratzmann, 2019). Overall, following an inductive, and iterative reading of our interview scripts, three types of welfare mediators emerged from the field data, summarised in Table 2.

In terms of frequency of occurrence, we found that informal social networks of acquaintances and family are the mediators most relied upon, followed by welfare advice agencies. EU migrant claimants commonly rely on several mediators simultaneously, in a two-step mediation process. In this respect, more informal contacts facilitate access to formal mediators, such as the designated welfare organisations who support migrant residents in making claims. The latter tend to be the most versed regarding legal entitlements and administrative procedures, as such knowledge can be considered to be part of their professional role, but do not always speak languages other than German, whereas informal mediators commonly may be well equipped in bridging language gaps, but not necessarily other types of knowledge asymmetries.

The data we collected allow conclusions to be drawn on how EU migrant applicants commonly reach out for external support once they want to start a claim process, but do not know their exact entitlements, or where and how to apply (see Ratzmann, 2020). For instance, an Anglophone respondent living in Germany described her German native partner as having played a key role in explaining "tiny things" about how the system worked. Without his help she believed she would not have succeeded in making a claim:

I wouldn't have known I have these rights. My partner explained to me that I have these rights... a system which is completely new to you.

He not only acted as an interpreter, translating from English to German, but also provided her with the knowledge of the behavioural norms which welfare administrators expected to be known. Her partner effectively bridged both linguistic and procedural knowledge gaps, in a double translation process. Another example is a Polish citizen who had received benefits from his local welfare authority, but whose claim was rejected by his new city borough's authority after he had moved within Berlin. The respondent appealed to the local social court with the support of a local community worker, whoknowing about the procedures and the entitlementsfiled the appeal for him. Commonly, migrant counsellors are instrumental in realising a substantive claim in practice. They usually explain the EU migrants' rights and duties and guide them through the claiming process, including the appeal if necessary (interviews with key informants, Germany). Third-parties also mediate the substantive knowledge deficits regarding the steps involved in the administrative procedure, which appears more pronounced for foreign claimants, as this welfare counsellor in Germany explained:

Some claimants think that it does not matter if they do not provide a certain document. It's not only a problem of miscommunication but of misunderstanding.

Our research finds that both extended personal social networks and not-for-profit organisations play a crucial role in the welfare mediation process. They not only provide information to counter knowledge deficits and speak on behalf of EU migrants who may not be able to converse in German, but, through their role as translators, empower their clients vis-à-vis welfare administrators when claiming entitlements.

In addition, some EU migrants are assisted by private mediators. This could include former employers advising them how to claim social benefits in Germany. For instance, staff from human resource departments sometimes supports their foreign employees in preparing the necessary paperwork:

I was finishing this job, and the prospect of being unemployed was kind of, eh, very openly discussed within the lab I was.... They explained the process.... found that really, really helpful... made you feel empowered.

Moreover, designated private advisors regularly offer their services to EU migrants (not to be confused with state-financed migrant counsellors). As part of their

Table 2. A typology of welfare mediators.

\begin{tabular}{|c|c|c|c|}
\hline $\begin{array}{l}\text { Type of welfare } \\
\text { mediator }\end{array}$ & Examples & $\begin{array}{l}\text { Relationship with } \\
\text { EU migrants }\end{array}$ & $\begin{array}{l}\text { Trade-off between rootedness in the } \\
\text { institutional system vs. Direct accessibility }\end{array}$ \\
\hline $\begin{array}{l}\text { Designated migration } \\
\text { counsellors }\end{array}$ & $\begin{array}{l}\text { National welfare organisations, } \\
\text { community-based associations }\end{array}$ & Formal & Strong-Low \\
\hline Private mediators & $\begin{array}{l}\text { Tax advisors, employment } \\
\text { recruitment agencies, } \\
\text { former employers }\end{array}$ & Semi-formal & Medium-Partial \\
\hline $\begin{array}{l}\text { Personal } \\
\text { relationships }\end{array}$ & $\begin{array}{l}\text { Acquaintances, friends, family, } \\
\text { partners/spouses, colleagues }\end{array}$ & Informal & Weak-High \\
\hline
\end{tabular}


business model, such private advisors inform about social entitlements, and offer translation services in different EU languages. However, several representatives of welfare authorities and rights advocacy groups casted doubt on the legitimacy of certain such mediators, questioning their loyalties and moral ambiguity, and whether they were acting in the interest of their clients (also see Lindquist, 2015). Key informants alluded to how such a third-party would not always translate in the interest of their clients, characterised by a discrepancy between what was said and done. Within our interview sample, they commonly assumed roles of (self-declared) tax advisors and book-keepers, raising awareness of the types of benefits which could be claimed, as this French respondent living in Germany explained:

Our tax advisor made us aware that we could top up our income.... He told us he would help us, for a fee, in case we decided to go for it, as he knows our situation well.

Key informants pointed us to some illegal mediation practices, describing them as "letterbox companies." For instance, a representative of the Bulgarian embassy in Berlin elucidated how such firms would provide EU applicants with a fake employment contract to facilitate benefit access, in exchange for a sum of money of up to 2000 euros. According to a Polish community worker, a shared language and country of origin, indicating belonging, may inspire misplaced trust and confidence in this context, whereby clients often sign papers without understanding them. In short, private mediators could be "an assistance on the one side, and a problem on the other side," as one welfare administrator in Germany framed it.

In terms of accessibility, our data suggest that while there is a low threshold for connecting to informal mediators, who tend to be part of migrants' extended social networks, other, more formalised mediation processes require knowledge about the existence, and the type, of services mediators can offer. According to our key informants, both in Austria and Germany, personal contacts tend to leverage access to organisations whose mandate is to support EU migrant claimants. Overall, the more informal a mediation relation is, the more trust tends to be involved, and the less effort is required to initiate a mediation process. But informal mediators come at the price of a marginally institutionalised position, which leads to lower institutional leverage, in contrast to professionally mandated meditators, who welfare authorities perceive as more legitimate counterparts, and who hence have a more authoritative voice. As illustrated by a welfare administrator in Austria who pointed to the advocacy role of local not-for-profit organisations: "Instead of threatening with a lawyer, EU migrants threaten with [this organisation]." The credibility formal mediators could gain from their institutional embeddedness may imply higher chances of redressing local-level power imbalances, but simultaneously engenders lower accessi- bility, because their existence is unknown, and a potential lack of trust from their clients who may consider them as state-run, and hence, from their perspective, less trustworthy institutions. In short, the effectiveness of welfare mediators in empowering their clients, and in translating rights into de facto benefits receipt, depends on the trade-off between their rootedness in the institutional setting of welfare provision and their accessibility for the individual EU migrant seeking support during the claims-making process.

\section{Discussion}

EU migrants who do not (fully) know about formal entitlements or procedures, and do not speak the language, are typically in a vulnerable position vis-à-vis welfare administrators who make decisions about their claim. In short, "knowledge is power," or, in other words, knowledge asymmetries can translate into, or exacerbate existing, power asymmetries at street-level when seeking to affirm social entitlements. Such asymmetries open up spaces for welfare mediation. Welfare advice or community organisations, family, friends, partners, or colleagues can bridge communication gaps and clarify misconceptions about legal entitlements and obligations embedded in the claiming system. Ultimately, they can help EU migrant applicants secure a benefit claim in practice by empowering their clients to actively assert their social rights. However, as our typology illustrated, not all welfare mediators can be regarded as equally effective in redressing power asymmetries, and so to speak, level the playing field. Their ability to attenuate knowledge asymmetries depends on their own knowledge base, and their anchorage or positioning within the institutional system. For instance, if mediators interpret the vague legal eligibility criteria in a restrictive way, they may discourage EU migrants from applying for benefits, or from a legal appeal if the claim was denied. Others may even generate new forms of vulnerabilities through their exploitative relationship with clients. From the perspective of welfare authorities, the ambiguous character of certain private mediators, such as tax advisors, can give rise to challenges to their work if the latter are knowledgeable about potential legal loopholes, and may encourage or assist their clients in committing welfare fraud, for instance through fake employment contracts. In such extreme cases, an inversion of the power asymmetry to the detriment of welfare administrators may be the consequence, they suspect.

Regarding potential implementation disparities, although no clear differences of patterns of implementation between the two countries studied were observed, a rural versus urban cleavage seems to emerge, with welfare mediation processes being more present in bigger agglomerations. This can be associated with the stronger presence of migrant counselling services in urban areas, offering formal assistance in claimsmaking, including legal appeals in the case of rejections. 
Moreover, infrastructure, and resources to mediate knowledge asymmetries, seem less developed within rural welfare authorities. For instance, a welfare administrator in Germany mentioned that they "can't call in an interpreter from Munich every time" they were confronted with an EU migrant whose language the staff could not speak. Our data also suggest that some streetlevel bureaucrats tend to be less familiar with the legal rules in such rural areas, as they process fewer cases of EU migrants and hence lack practice. In such rural areas, this could imply smaller knowledge asymmetries, and may, in some cases, contribute to more generous case processing (see Heindlmaier, 2018).

Finally, our interviews provide an outlook beyond the micro-level interactions between EU migrant claimants and street-level bureaucrats when shifting the focus onto welfare authorities themselves. Our findings point to the role of the institutional environment in which individual welfare mediation is embedded (which, however, goes beyond the scope of this study). In short, while street-level organisations can ease or reinforce claimants' knowledge asymmetries in the first place, they equally enable or restrict opportunity structures for welfare mediation processes depending on the openness or restrictive outlook of a social administration. For instance, some Berlin-based welfare authorities seek pro-active collaboration with migrant counselling services when processing EU migrant citizens' claims. As per our interviews with welfare administrators in Germany, this could concern legal queries or translation services. Additionally, some local institutions are characterised by in-house diversity policies, which may alleviate some of the knowledge asymmetries EU migrants typically encounter. These policies include the translation of signage within the authority into several foreign languages, such as English, French, or Polish, as well as the placement of complementary pictograms on the signs. Some local welfare authorities also started offering services in languages other than German and to provide information sheets in house or online in different languages. Local management employed a certain percentage of staff with migration experience, whose language competencies were recorded in a central database. Such institutional responses to some of the stumbling blocks to claiming, like language, may allow power asymmetries to be alleviated from within, and thus counter the need for welfare mediation in the first place.

As the described knowledge asymmetries partly originate from the institutional practices of welfare authorities, one could argue that they should be tackled in a more structural manner. To date, however, intercultural or diversity policies in social administration may sometimes be no more than lip service (Ratzmann, 2019). Instead, diversity-related challenges at streetlevel are individualised. Indirectly, the relevant welfare administrators adopt a "deficit perspective" of what EU claimants lack, in terms of linguistic skills and tacit knowledge, compared to national applicants. Solving such problems is outsourced to the claimants themselvesand creates a pivotal role for welfare mediators as individual actors who can intervene during the benefit claiming process at street-level.

\section{Conclusion}

While research to date points to how non-active EU migrants, or those involved in atypical work, commonly remain excluded from social assistance benefits, this article focusses on an under-researched barrier to claiming social entitlements, namely the interaction experiences between EU claimants and street-level bureaucrats. We focus on the knowledge, and resulting power, asymmetries at street-level. While power asymmetries may apply to most claimant groups, they are more striking in the context of the EU freedom of movement, as partially ambiguously defined social entitlements may increase room for administrative discretion, and thus exacerbate knowledge and related power asymmetries.

EU migrants do not usually remain merely passive and powerless claimants. Instead, they tend to actively shape the claiming process, relying on third-party mediators to substantiate their social rights claims in practice. The article discussed how knowledge asymmetries call for mediated access into the welfare system in practice, and what role such mediation processes play in the state-claimant interaction. After briefly outlining the functions of welfare mediation, the article characterised the different types of mediators based on a typology we developed from the data. Our findings show how third parties can change the power constellation between claimants and street-level bureaucrats in unexpected ways, enabling access to social benefits and services for otherwise excluded EU migrant citizens. Yet, the former may equally create new, and additional power asymmetries and room for exploitation, depending on their moral character.

While our contribution offered a first typology of welfare mediators, further research could assess whether there are systematic differences between the types of welfare mediators different groups of migrants rely on, for instance regarding education or age. Our exploratory findings suggest, for example, that better educated migrants are better equipped, in terms of social capital, to reach out to formal welfare mediators, such as counselling services. Additionally, not only knowledge asymmetries relating to the functioning of the bureaucratic system, but also perceptions based on habitus or physical appearance, may impact the claimsmaking process, and thus warrant further attention. Moreover, even though we focus on mediation processes at street-level-of third parties intervening on behalf of EU migrant claimants, some welfare mediators seek to impact administrative claims-processing by systematically intervening on both sides of the street-level interaction. This particularly concerns the role of not-for-profit welfare counsellors who commonly fulfil an advocacy 
function, seeking to change the institutional routines of processing EU migrant claims (see Bruzelius, 2020). In this context, the notion of welfare intermediation could be further conceptualised.

Finally, our article focusses on the role of mediators with regard to migrants' welfare access, but the findings may also be transferable to the migration-labour-nexus, i.e., to the relation between employers and EU migrant citizens. To what extent our findings on the structurally "unequal" relationship are transferable, and which role job broker agencies play, necessitates more detailed exploration. Making employment services more accessible for EU migrants could be of potential interest for the society of destination as, at least, Germany and Austria, need qualified migrant labour. Overall, diversityoriented public services could make the national welfare service system more accessible, as well as any publicly financed and state-run service more generally.

\section{Acknowledgments}

We are both indebted to our interviewees who made this research possible. Nora Ratzmann would also like to extent a special thanks to her PhD supervisors Harley Dean and Isabel Shutes, at the London School of Economics, and the Leverhulme Trust UK, whose funding made this research project possible. Anita Heindlmaier would like to thank her PhD supervisor Michael Blauberger and the Norface/FWF project TransJudFare. Finally, we would like to thank three anonymous reviewers, Stefan Wallaschek, the participants of the workshop "Migration, Social Welfare and 'Social Cohesion'" from 28 and 29 January 2021, and the members of the FWF/DFG project Rebalancing the Enlarged Single Market for their constructive comments.

\section{Conflict of Interests}

The authors declare no conflict of interests.

\section{Supplementary Material}

Supplementary material for this article is available online in the format provided by the author (unedited).

\section{References}

Amelina, A., Carmel, E., Runfors, A., \& Scheibelhofer, E. (Eds.). (2020). Boundaries of European social citizenship. EU citizens' transnational social security in regulations, discourses and experiences. Routledge.

Blauberger, M., \& Schmidt, S. K. (2017). Free movement, the welfare state, and the European Union's overconstitutionalization: Administrating contradictions. Public Administration, 95(2), 437-449.

Brodkin, E. Z., \& Majmundar, M. (2010). Administrative exclusion. Organizations and the hidden costs of welfare claiming. Journal of Public Administration
Research and Theory, 20(4), 827-848.

Brubaker, R. (2014). Linguistic and religious pluralism: Between difference and inequality. Journal of Ethnic and Migration Studies, 41(1), 3-32.

Bruzelius, C. (2019). Freedom of movement, social rights and residence-based conditionality in the European Union. Journal of European Social Policy, 29(1), 70-83.

Bruzelius, C. (2020). Non-for-profits and EU citizens' cross-border social rights in different welfare states. Journal of Social Policy, 49(3), 601-621.

Bundesagentur für Arbeit. (2011). Inanspruchnahme von Dolmetscher- und Übersetzungsdiensten sowie Regelungen für den Einsatz und die Verwendung von Dienstausweisen [Use of interpreting and translation services as well as regulations for the deployment and application of service cards] (Internal Guidance HEGA 05/11-08).

Carmel, E., \& Paul, R. (2013). Complex stratification. Regions and Cohesion, 3(3), 56-85.

Chiswick, B. R., Lee, Y. L., \& Miller, P. W. (2018). A longitudinal analysts of immigrant occupational mobility. A test of the immigrant assimilation hypothesis. International Migration Revue, 39(2), 332-353.

Consolidated version of the Treaty on the Functioning of the European Union, 2012. http://data.europa.eu/ eli/treaty/tfeu_2012/oj

de Jong, S. (2015). Female migrants as "mediators between two worlds": Spatio-temporal articulations of intersectional positions. Journal of Diversity and Gender Studies, 2(1/2), 111-126.

Demazière, D. (1996). Des réponses langagières à l'exclusion. Les interactions entre chômeurs de longue durée et agents de l'ANPE [Language responses to exclusion. Interactions between long-term unemployed and ANPE agents]. Mots, 46, 6-29.

Directive 2004/38/EC of the European Parliament and of the Council of 29 April 2004 on the right of citizens of the Union and their family members to move and reside freely within the territory of the member states amending Regulation (EEC) No. 1612/68 and repealing Directives 64/221/EEC, 68/360/EEC, 72/194/EEC, 73/148/EEC, 75/34/EEC, 75/35/EEC, 90/364/EEC, 90/365/EEC and 93/96/EEC. (2004). Official Journal of the European Communities, L 158/77.

Dittmar, V. (2016). Arbeitsmarktintegration für Migranten fördern: Potenziale der Jobcenter [Promoting labour market integration for migrants: Potentials of the job centres]. wbv Bertelsmann.

D. M. Levin v Staatssecretaris van Justitie, Case 53/81, ECLI:EU:C:1982:105 (1982).

Dubois, V. (2010). The bureaucrat and the poor. Encounters in French welfare offices. Ashgate.

Dubois, V. (2014). The state, legal rigor, and the poor. The daily practice of welfare control. Social Analysis, 58(3), 38-55.

Eckhard, S. (2021). Bridging the citizen gap: Bureau- 
cratic representation and knowledge linkage in (international) public administration. Governance, 34(2), 295-314.

Ehata, R., \& Seeleib-Kaiser, M. (2017). Benefit tourism and EU migrant citizens. Social Policy Review, 29, 181-198.

Elisabeta Dano and Florin Dano v Jobcenter Leipzig, Case C-333/13, ECLI:EU:C:2014:2358 (2014).

European Commission. (2020). 2019 annual report on intra-EU labour mobility. https://ec.europa.eu/ social/main.jsp?catld=738\&langld=en\&publd= 8242\&furtherPubs=yes

Gordon, L. K. (1975). Bureaucratic competence and success in dealing with public bureaucracies. Social Problems, 23(2), 197-208.

Hasenfeld, Y., Rafferty, J. A., \& Zald, M. N. (1987). The welfare state, citizenship, and bureaucratic encounters. Annual Review of Sociology, 13, 387-415.

Heindlmaier, A. (2018). Deep Europeanization? How EU member states administer free movement of persons and cross-border access to social benefits at the street-level [Doctoral dissertation, University of Salzburg]. ePLUS. https://eplus.uni-salzburg.at/ ?lang=en

Heindlmaier, A., \& Blauberger, M. (2017). Enter at your own risk: Free movement of EU citizens in practice. West European Politics, 40(6), 1198-1217.

Infantino, F. (2013). Bordering the window. The allocation of Schengen visas at the Italian embassy and the consulate in Marocco. In D. Bigo, S. Carrera, \& E. Guild (Eds.), Foreigners, refugees or minorities. Rethinking people in the context of border controls and visas (pp. 227-240). Ashgate.

Jobcenter Berlin Neukölln v Nazifa Alimanovic and Others, Case C-67/14, ECLI:EU:C:2015:597.

Kramer, D., Sampson Thierry, J., \& van Hooren, F. (2018). Responding to free movement: Quarantining mobile union citizens in European welfare states. Journal of European Public Policy, 25(10), 1501-1521.

Lafleur, J.-M., \& Mescoli, E. (2018). Creating undocumented EU migrants through welfare: A conceptualization of undeserving and precarious citizenship. Sociology, 52(3), 480-496.

Lindquist, J. (2015). Brokers and brokerage, anthropology of. In J. D. Wright (Ed.), International encyclopaedia of the social \& behavioral sciences (pp. 870-874). Elsevier.

Lipsky, M. (1980). Street-Level bureaucracy. Dilemmas of the individual in public services. SAGE.

Marrow, H. B. (2009). Immigrant bureaucratic incorporation: The dual roles of professional missions and government policies. American Sociological Review, 74, 756-776.

Martinsen, D. S., Blauberger, M., Heindlmaier, A., \& Thierry, J. S. (2019). Implementing European case law at the bureaucratic frontline: How domestic signalling influences the outcomes of EU law. Public Administration, 97(4), 814-828.

Ratzmann, N. (2019). Caught between the local and the (trans)national: EU citizens at the front-line of German welfare policy [Doctoral dissertation, London School of Economics]. LSE Theses Online. http://etheses.Ise.ac.uk/3982

Ratzmann, N. (2020). EU migrants' experiences of claimsmaking in German job centres (Working Paper 45). International Inequalities Institute, London School of Economics.

Ratzmann, N. (2021). Deserving of social support? Street-level bureaucrats' decisions on EU migrants' benefit claims in Germany. Social Policy and Society, 20(3), 509-520. https://doi.org/10.1017/S147 4746421000026

Rice, D. (2013). Street-level bureaucrats and the welfare state: Toward a micro-institutionalist theory of policy implementation. Administration \& Society, 45(9), 1038-1062.

Scheibelhofer, E., \& Holzinger, C. (2018). “Damn it, I am a miserable Eastern European in the eyes of the administrator": EU migrants' experiences with (transnational) social security. Social Inclusion, 6(3), 201-209.

Scheibelhofer, E., Holzinger, C., \& Draxl, A.-K. (2021). Linguistic diversity as a challenge for street-level bureaucrats in a monolingually-oriented organisation. Social Inclusion, 9(1), 24-34.

Tuckett, A. (2015). Strategies of navigation: Migrants' everyday encounters with Italian immigration bureaucracy. The Cambridge Journal of Anthropology, 33(1), 113-128.

van Oorschot, W. (1991). Non-take-up of social security benefits in Europe. Journal of European Social Policy, 1(1), 15-30.

Warin, P. (2010). Le non-recours: Définition et typologies [Non-take-up: Definition and typologies]. Odenore. Weber, M. (1922). Wirtschaft und Gesellschaft [Economy and society]. Mohr.

\section{About the Authors}

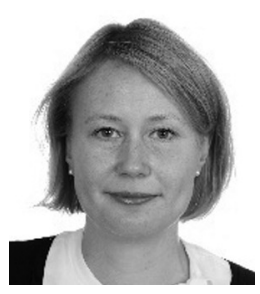

Nora Ratzmann is a post-doctoral researcher, whose experience include assignments at Oxford University, RAND Europe, UNESCO, and the Expert Council of German Foundations for Migration and Integration. Her focus is on migration politics and social inequality. She currently holds positions as a research fellow at the German Center for Integration and Migration Research (DeZIM) and the Centre for Analysis of Social Exclusion (CASE), LSE. Nora obtained her PhD in social policy from the London School of Economics in 2019. 


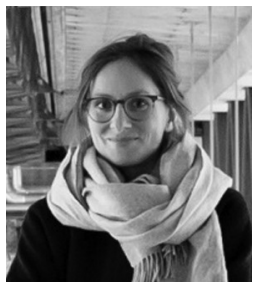

Anita Heindlmaier is a postdoctoral researcher in the transnational DACH project Rebalancing the Enlarged Single Market (RESiM) at the University of Salzburg, Salzburg Centre of European Union Studies, Department of Political Science and Sociology. Before, she worked as a doctoral researcher in the international NORFACE project Transnationalization and the Judicialization of Welfare (TransJudFare). Her research focuses on the EU, free movement and migration, social and labour rights, as well as implementation of EU law and policies. 